\title{
„HUDEBNĚ VĚDECKÝ KOLEKTIV MÁ ZA SEBOU JIŽ TAKÉ PĚKNÉ VÝSLEDKY“ - HUDEBNÍ VĚDA MIMO UNIVERZITU V PRVNÍ POLOVINĚ PADESÁTÝCH LET V BRNĚ
}

Předkládaná studie je věnována jak samotnému vzniku, fungování a postavení hudebně vědného kolektivu v rámci brněnské odbočky Svazu československých skladatelů, tak též komplikovaným společenským okolnostem, které určovaly jeho strukturu, formu i vlastní obsah činnosti. Nedílnou součástí je též pokus o snad spíše tezovité naznačení kulturně společenského prostoru hudební vědy, jejího napojení na žitou a probíhající současnost, samozřejmě primárně v dikci budování socialismu, ale mnohé z naznačeného snad může posloužit coby nekauzální paralela se současnou transparentní společností, kdy na základě fikce ekonomické potřebnosti je vědecké paradigma potlačováno všeobjímající potřebou komunikace, nekritické flexibility a neuchopitelné tekutosti. Důraz je tak kladen, nejen na historické souvislosti, ale též na samotnou otázku postavení hudební vědy mimo rámec univerzity $\mathrm{v}$ kontextu první poloviny padesátých let v bývalém Československu.

Předkládaná, doposud pouze rozpracovaná, rozšířená př́ípadová studie, z pohledu mikrohistorického definovaná spiše geograficky, než čistě antropologicky, je postavena na prolínání i rozporu společenského požadavku jasné, i když nedefinovatelné umělecké doktríny a jejího naplňování či nenaplňování, a to jak v otázkách distribuce „kánonu“ mezi hudebníky i celou společnost (rozuměj coby analýza systému a organizace hudebního života), tak v rovině estetické (tedy vlastní proměna jazyka). Inspirován Foucaultem tak sice hledám „kolektivní diskurzy“ a dle Bourdieho popisuji mocenské „strategie“, ale zvolené období a především místo charakterizuji spíše „taktikou poddaných“, jejichž svoboda byla značně okleštěna, a „praktikami“ či dokonce „kutilstvím“ nově „konstruované" komunity mocných. Při práci s prameny (jejich heteroglosií) je tak kladen velký důraz na diskrepanci mezi představou, ideologií, teorií (strategie) a reálnou schopností či ochotou (praktika) brněnských osobností naplnění či nenaplnění těchto představ (taktika). Kolektivní diskurz byl definován zdeformovaným marxismem, jako jedinou cestou $\mathrm{k}$ socialismu, $\mathrm{k}$ ideálu beztř́dní společnosti ve víre v kolektivního ducha společného budování. Umění, coby nadstavbě však byla 
přikládána mimořádná důležitost ve službě předkládané ideji. Mocenskou strategií bylo bezprecedentní prosazování ideologie socialistického realismu, principem „totalitního marketingu“ s vyloučením jakékoliv konkurence. Byla aplikována jak „,metoda biče“, tak též účinný postup „,chléb a hry“. Praktiky i taktiky poddaných v boji za lepší zítřky pak byly deformovány nekritickým optimismem, intelektuální výbavou nových kádrů, osobní nevraživostí i snahou urvat co se dá, jakož i touhou po důstojném životě či přirozenou snahou o přežití. Naplňovány poté byly uplatňováním manipulativních floskulí tematické teorie, jednoduchostí, ale též nutností kritiky a sebekritiky, jakož i neustále deklarovanou nejistotou kompetence i zodpovědnosti. Budiž smutným konstatováním a snad též historickou zkušeností, že o hudbu samotnou, coby znějící strukturu, v prvních poúnorových dekádách zas až tak moc nešlo.

Komunistický puč v únoru 1948 znamenal pro československou společnost radikální proměnu, která se nemalou měrou projevila též na poli kulturním a uměleckém. Svobodné tvorbě a projevu byla přiřknuta role ideologického nástroje sloužícího myšlence výchovy nového socialistického člověka žijícího v utopii beztřídní společnosti pod praporem Stalinova Sovětského svazu. ${ }^{1}$ Převodovou pákou systému ř́zení kultury se pro oblast hudby měla stát dobrovolná výběrová organizace, sdružující české a slovenské skladatele, hudební vědce a kritiky, jakož i koncertní hudební umělce. ${ }^{2}$ A tak se i stalo. Už 22. února 1946 vznikl v Praze Syndikát českých skladatelů, organizace, která se podílela na I. mezinárodním sjezdu skladatelů a kritiků uspořádaném při př́ležitosti prvního Pražského jara 1947. Od 15. 10. 1948 vydávala časopis Hudební rozhledy. Na II. mezinárodním sjezdu skladatelů a hudebních vědců (Praha 20.-29. 5. 1948) byl zvolen př́pravný výbor Mezinárodní společnosti pokrokových skladatelů a hudebnich vědci̊, čímž se již projevilo př́mé ovlivnění organizace novou politickou situací. Aplikace ideových směrnic II. sjezdu na domácí situaci byla předmětem jednání I. pracovního sjezdu skladatelů a hudebních vědců Československa (26.-28. 9. 1948 v Praze). Př́ té př́ležitosti se sešly oba dosud odděleně působící syndikáty českých a slovenských skladatelů. Porady vyvrcholily na společné schůzi obou syndikátů v prosinci 1948 v Praze, kde byl vyhlášen rámcový pětiletý tvưrčí plán. ${ }^{3}$ Předpokládalo se, že právě Syndikát českých skladatelů se stane jedinou vrcholnou

1 Srov. např. OLŠÁKOVÁ, Doubravka. Věda jde k lidu! : československá společnost pro šǐrení politických a vědeckých znalostí a popularizace věd v Československu ve 20. stolení. Vyd. 1. Praha: Academia, 2014, s. 22; LUKEŠ, Igor. Československo nad propastí Selháni amerických diplomatũ a tajných služeb v Praze 1945 - 1948. Praha: Prostor, 2014, s. 258-261; APPLEBAUMOVÁ, Anne. Železná opona Podrobení východni Evropy 1944-1956. Praha - Plzeň: Beta-Dobrovský Ševčí, 2014, s. 299-302; KAPLAN, Karel. Protistátní bezpečnost 1945-1948 Historie vzniku a puisobení STB jako mocenského nástroje KSČ. Praha: Plus, 2015; ad.

2 Srov. KNAPÍK, Jiří. V zajetí moci. Kulturní politika, jeji systém a aktéři 1948 - 1956, Libri: Praha 2006, s. 46-47.

3 Srov. CHMELAŘOVÁ, Vlasta. Syndikát českých skladateli̊, in. Kolektiv autorů. Slovnik české hudebni kultury, Praha: Editio Supraphon, 1997, s. 901, HAVLÍK, Jaromír. Jaroslav Doubrava, Skladatel v sevření dvou totalit, Praha: NAMU, 2002, s. 225-226. 
organizací hudebních tvůrců, která zaručí zájmy všech oblastních uměleckých skupin po všech stránkách. Slovo „syndikát“ však přespř́liš evokovalo období první republiky, i proto došlo k přejmenování a transformování Syndikátu českých skladatelů na Svaz československých skladatelů, který byl obdobou Svazu sovětských skladatelů. K této transformaci se přistoupilo počátkem roku 1949 a dokončena byla ustavující schůzí Svazu ve dnech 14. - 15. května 1949 v Praze, kdy oba syndikáty, český i slovenský, jakož i řada dalších spolků definitivně zanikají a jsou nahrazeny monstrózní, monopolní organizací.

V roce 1949 mohla vzniknout odbočka SČS v kraji, kde bylo minimálně 20 členů Svazu, ale již od počátku se počítalo s menším množstvím poboček, které by zastupovali více krajů. V roce 1949 tak vzniká jediná odbočka v Česku a to právě v Brně. Od svého počátku v roce 1949 až do září 1950 byl Svaz dělen to tzv. tvůrčích či pracovních komisí, nebo kolektivů, které byly poté nahrazeny sekcemi a to skladatelskou, hudebních vědců a kritiků a od roku 1952 též nově sekce koncertních umělců, sekce byly občas i po transformaci nazývány komisemi, tudíž při dalším oborovém dělení se používalo termínu subkomise (např. subkomise velkých forem u skladatelské sekce, subkomise pedagogická a instruktivních skladeb u sekce hudebně vědné a subkomise dechových nástrojů u sekce koncertních umělců). ${ }^{4}$ Ještě neustavené, ale již existující sekce skladatelů a hudebních vědců pak rovněž zakládaly Kluby, kde byly přehrávány nové skladby, řešeny ožehavé ideologické či hudebně teoretické problémy. ${ }^{5}$

Samostatný hudebně vědecký kolektiv byl ustaven až na základě změny organizačního řádu k 1. lednu 1952. Do té doby bylo „služeb“ hudebních vědců využíváno spíše v rámci vlastní organizace, při řešení otázek hudebního školství, pro odborné referáty a ve vydavatelské komisy. Je třeba si uvědomit, že do roku 1952, kdy zákonem č. 52 / 1952 byla zř́zena Československá akademie věd, se nacházíme v určitém vědeckém vakuu. Plná činnost univerzitních pracovišt' po válce ještě nebyla obnovena a z personálních důvodů snad ani býti nemohla, akademie coby „hlavní centrum vědeckého bádáni““6 ještě neexistovala a navíc především ideologická strategie požadovala, aby „věda sloužila lidu“" což se projevovalo mimo jiné úmornou diskusí o dialektice stranickosti a objektivity ${ }^{8}$ Umělci a potažmo též vědci nebyli v rétorice komunistické moci označování coby lid, ale jako „pracující inteligence.“ Jejich postavení bylo hierarchicky vlastně podřízené a „teprve ve službách lidu se inteligence stává součástí lidu. Tedy nikoliv sdíleni poznatkì ve jménu pokroku, ale služba ve jménu převýchovy."

4 Organizační řád Svazu československých skladatelů + poznámky, 1950.

5 Srov. PANTƯČEK, Viktor. Vznik brněnské odbočky Svazu československých skladatelů 1949-1951. Opus musicum, 2012, roč. 44, č. 2, s. 37-48.

6 Zákon č. 52 / 1952 sb., o Československé akademii věd ve znění pozdějších předpisů (29. řijna 1952).

7 NEJEDLÝ, Zdeněk; ŠTOLL, Ladislav. Věda jde s lidem. Praha: Orbis, 1952, s. 4.

8 Srov.: tamtéž; MUKAǨOVSKÝ, Jan. Stranickost ve vědě a umění. Praha: Orbis, 1949, s. 16.

9 OLŠÁKOVÁ, Doubravka. Věda jde k lidu! : československá společnost pro šíření politic- 
Hlavním cílem hudební vědy tak mělo být stanovení úkolů a cílů nejmladší skladatelské generace na cestě k socialistickému realismu, kritika a sebekritika dosavadní tvưrčí činnosti a především hledání teoretického rámce pro utváření socialistického realismu v hudbě, včetně revize dějin hudby, vždyt' hudba měla již od nepaměti směřovat $\mathrm{k}$ lidově demokratické myšlence. ${ }^{10}$ Především léta 1949-1950 byla ve znamení individuálního hledání cesty a pojetí ideologie realismu v hudbě a vůbec vlastního postavení hudby, potažmo hudební vědy ve společnosti. Společnost se nepochybně radikalizovala, ale škála představ a př́stupů $\mathrm{k}$ žité skutečnosti a především $\mathrm{k}$ budoucnosti byla poměrně pestrá, výrazně se profilovaly především dva proudy, na první pohled rozlišitelné coby „radikální a umírněné křŕdlo“. Oba směry se nelišily ve stanoveném cíli dosažení socialistického realismu, ale značně rozporné bylo prijímání či lépe vztah ke kulturnímu dědictví, především $\mathrm{k}$ hudbě meziválečného období, různá chápání estetiky socialistického realismu a též samotná představa o metodách prosazování kulturní politiky. V kulturně společenském prostoru Československé lidové demokracie je tento rozpor důkladně rozpracováván Jiřím Knapíkem, především na srovnání činnosti Kulturního a propagačního oddělení, spadajícího př́mo pod ÚV strany a kulturními ministerstvy, která si zachovávala nedeklarovanou samostatnost. Konkrétně především na postavách Gustava Bareše a Václava Kopeckého. Při poněkud zjednodušeném nahlížení se tak jednalo o střetnutí „ostř́ílených komunistư“, kteří bojovali za sociální práva již v období buržoazní první republiky a své přesvědčení utužili v litých bojích druhé světové války a „nastupující dravce“ z řad mladých kádrů, vstupujících do boje za mír a socialistickou budoucnost po vítězném únoru 1948. Již z výše uplatněného, snad i poněkud nekorektního, popisu je zřejmé, že vyhrocená situace nebyla způsobena pouhou polaritou ideálů, ale rovněž velmi výrazným, bohužel bytostně lidským, mocenským bojem a rovněž logickým generačním rozkolem. Mimo oblast hudby jsou v tomto ohledu dobře známé okolnosti např́klad odstavení Emila Filly z pozice předsedy Svazu výtvarných umělců, vstup dělnických kulturních komisí (porot) a jejich vliv na filmovou produkci, především v souvislosti s filmovým zpracováním povídky Františka Langra Dvaasedmdesátka, nebo dlouhodobé snahy o dehonestování Vítězslava Nezvala. Jako př́íklad z hudební oblasti pak můžeme uvést diskusi z 28. června 1950 vedenou nad Sonátou pro housle a klavír od Osvalda Chlubny.

Na klubovním večeru byla přítomna ,pražská invaze“ (slovy Ludvíka Kundery) - Miroslav Barvík, Antonín Sychra a Josef Stanislav. Diskuse byla věnována přehrávce 5. smyčcového kvartetu Viléma Petrželky a Sonáty pro housle a klavír Osvalda Chlubny. Zatímco Petrželkova skladba byla přijata velmi vstř́ícně a označena jako vzorová. Skladba Chlubnova vyvolala bouřlivou polemiku. Bylo mu vytknuto - splývání disonance a konsonance (Antonín Sychra), nenárodní

kých a vědeckých znalostí a popularizace věd v Československu ve 20. stolení. Praha: Academia, 2014, s. 29.

10 BARVÍK, Miroslav. Návrh osnov dějin hudby na konservatoři. In. Hudební rozhledy, 1951, roč. 4 , č. 3, s. 12-13. 
charakter - uplatnění burlesky, atd. „Dílo prof. Petrželky je dillem, které by jistě zaujalo jakékoliv obecenstvo. Dílo Chlubnovo nás nechalo poněkud na rozpacích, neřeklo nám nic konkrétního, nic určitého..." (Jaroslav Tomášek) „Dnes jsme již od Února hodně daleko. Skoro každý skladatel by si rozmyslil provedeni skladeb vzniklých před únorem. Je zajímavé, že pobočka v Brně si dovolila provést tuto skladbu. Sonáta ukázala, že je dílem z doby umělecké tvorby s výrazem jiným. Jsou zde znaky rozkladu buržoasni společnosti. Je to vyjádřeni února z posic formalistických apod. Není to vyjádření února nové třídy." (M. Barvík) Chlubna se obhajoval coby skladatel, nikoliv znalec stranických požadavků. „Hned, když jsem svou Sonátu zadával, pochyboval jsem, že projde. Úvodem jsem to naznačil. Slyšel jsem zde tolik věcí-Kapra, Stanislava, Barvika, Sychru - a jsem rád, že Sonáta byla kritisována. Nejsem však rád, že oni nejsou a na plenárním zasedáni nebyli kritisováni. Sonátu mi nikdo nezabije, nic na ní nezměním...." V diskusi bylo využíváno řady dobových floskulí především M. Barvíkem, Janem Kaprem a J. Stanislavem. ${ }^{11} \mathrm{Z}$ výše napsaného je snad dostatečně zřejmé, že o vlastní hudební kvality skladeb až tak nešlo. Vilém Petrželka patřil k progresivnější linii Janáčkových žáků a za svoji meziválečnou tvorbu se dočkal po Únoru zdrcující kritiky, kdy byl nejprve v roce 1949 na dvacet měsíců ze Svazu vyloučen a v dubnu 1950 při prvním plenárním zasedání v úvodním projevu Miroslavem Barvíkem označen za formalistického skladatele. Na základě těchto událostí se Petrželka podrobil sebekritice a svého osobitého kompozičního jazyka se plně vzdal a v duchu Ždanovova odkazu se ,přetvořil a obrátil tvář́ ke svému lidu“. ${ }^{12}$ Naproti tomu Osvald Chlubna byl sice akčním výborem Národní fronty poměrně netaktně sesazen z pozice předsedy Klubu moravských skladatelů, ${ }^{13}$ výraznějšího postihu se mu však nedostalo. Jeho veskrze tradiční kompoziční jazyk nevyvolával zásadnější pohoršení, a tudíž se jej Chlubna nevzdal a ani vzdávat nemusel. Představená kritika jeho Sonáty je tak spíše dokladem generačního rozporu a rozpakủ při přijímání fádních tezí socialistického realismu v hudbě. Pro korektnost si dovoluji ke srovnání předložit stručný citát $\mathrm{z}$ bohužel nesignovaného textu z 3. ročníku Hudebních rozhledů Tvůrčí úspěchy moravských skladatelů, který obsáhle reflektoval I. pracovní plenární zasedání brněnské odbočky české sekce Svazu československých skladatelů, která se konala v Brně ve dnech 16.-17. prosince 1950: „Zbývá ještě zmínit se o Osvaldu Chlubnovi. I v jeho tvorběje (podle plenárkové ukázky) patrný zlom a obrat k lepšímu, Chlubnovy skladby sloužily obyčejně všem hudebnikuim za přiklad vymyšlené, suché, úmorné hudby, která se všemi rafinovanostmi ubiji v člověku jakékoliv radostné vzruchy. Chlubnovy

11 Záznam o činnosti Klubu SČS v Brně dne 28. června 1950. Přehrávka skladeb Chlubny a Petrželky; DkCHK00000357.

12 ŽDANOV, Andrej Alexandrovič. O problémech sovětské hudby, 1948 In. Konfrontace 2 Měsičnik pro soudobou hudbu. Svaz českých skladatelů, Praha 1969, s. 54; srov. PANTŮČEK, Viktor. Vznik brněnské odbočky Svazu československých skladatelů 1949-1951. Opus musicum, 2012, roč. 44, č. 2, s. 37-48.

13 PANTU゚ČEK, Viktor. Musica politica Budování nového řádu. Opus musicum Hudební revue, Brno, 2007, roč. 39/2007, č. 1, s. 36-37. 
opery byly pověstné svou nedramatičností, jeho ostatni skladby svou délkou a nejasností. Symfonická báseň Z jara byla proto velkým překvapením. Je sice zase zbytečně dlouhá, ale má mnoho předností. Odhaluje v prvé radě onen známý fakt, že Chlubna je po technické stránce mistr svého oboru. Práce s thematy, instrumentace, formálni výstavba - to Chlubnovi nedělá obtiže, zvlást tenkrát, vyjadruje-li konkrétni představu (tentokrát radost člověka z jara). Horši je to s jeho invencí. Chlubnovy hudebni myšlenky nejsou dost životné, nosné a přesvědčivé. Avšak i po této stránce je jeho symfonická básen̆ Zjara velkým krokem vpřed..." ${ }^{14}$

Nebezpečně velký prostor pro diskusi, pro intepretaci socialistického realismu, ale též pro neoprávněné a nikým nekontrolované narůstání moci samozvaných kádrů, sice nijak nesnižovalo stalinistické, radikální vnucování jediného možného kulturního vzorce, ale více a více ohrožovalo nutnost byrokratického řízení a vůbec fungování jediného možného monopolního aparátu a to komunistické strany. Od počátku roku 1950 tak začalo postupně docházet k reorganizaci kulturního provozu, řada „nadbytečných“ organizací byla zrušena, byl zastaven bezhlavý nábor členů do strany i do oborových organizací, byly zahájeny prověrky stávajících členů i kandidátů a nově konstruovány požadavky pro přijímání nových zájemců, začalo oddělování zrna od plev a hledání nepřítele ve vlastních řadách. Nezvítězili ani umírnění, ani radikálové, ale individuálně ty osobnosti, které se dokázaly lépe ve zvoleném okleštění zorientovat a přizpůsobit, a jelikož odsouzení poražených bylo tak drastické, je již nevhodné dále o „umírněných“ hovořit. Ještě bych rád zmínil, že to co se odehrávalo na poli kulturní politiky téměř okamžitě rezonovalo na poli literárním a filmovém, s určitým zpožděním poznamenalo činnost výtvarníků a teprve v poměrně značném závěsu se projevilo též ve Svazu skladatelském či dalších hudebních organizacích, bylo-li to taktikou či spíše nedůsledností nedokáži posoudit, každopádně i díky tomu, odhlédneme-li od samotné nesmyslnosti otázky socialistického realismu v hudbě, nebyly čistky v hudebnických řadách tak hrůzostrašné, jako v jiných uměleckých oborech a rovněž hudební kultura byla spíše výrazně zprůměrována do všeobjímající šedi, než aby docházelo k natolik vulgárním projevům jako např́klad v oblasti literární. Vždyt' v období první pětiletky se většina socrealistických profilových skladeb rekrutovala bud' z děl vzniklých před Vítězným únorem (kantáta Neustupujte od Miloslava Kabeláče, Československá polka od Václava Dobiáše...), nebo byla definována spíše tematicky, ve smyslu obsahu literárního, než vlastní hudební strukturou. Vrat'me se však do Brna a k hudební vědě.

Neustálé „hony na čarodějnice“, zaměřené jednou proti genetice, jindy proti sociologii či hlubinné psychologii, ale také proti kybernetice, sémiotice či lingvistice. Neustálý boj proti náboženství, mystice, proti každé nemarxistické filozofii a estetice. Tím vším bylo vytvářeno ovzduší neustálé obklíčenosti nepřátelskými imperialisty a kosmopolity, prostředí neutuchajícího „třídního boje“ ${ }^{15}$ To vše se samozřej-

14 Tvưrčí úspěchy moravských skladatelů. In. Hudební rozhledy, 1951, roč. 3, č. 7, s. 6-7.

15 BERGER, Roman. Dráma hudby Prologomena k politickej muzikológii, HC Bratislava, 2000, s. 95-96. 
mě nemohlo vyhnout i hudební vědě. „Také brněnští hudební theoretikové byli plenárkou odhaleni jako pracovnici na slepé koleji. Jejich úvahy a knihy o dvojsměrných alternacich, o harmonických kombinacich, o skládáni tónin apod., jsou hotovou fraškou, která nikoho nezajímá a nikomu nepomáhá (ani v kladném, ani v záporném smyslu)Skutečný život pokrokových skladatelì, skutečný vývoj moravské soudobé hudby, jde naprosto mimo hřičky těchto učených muzikantü. A prece např. v Brně je tolik schopných kritikü, theoretikü, vědců! Je nepochopitelné, že kolektiv takových pracovitých lidí a takových vzdělaných odbornikü, jako jsou prof. Dr. Jan Racek, dr. Jiři Vysloužil, dr. Zd. Blažek, prof. Theodor Schaefer a mnozi jiní, nedovedl ještě na pưdě odbočky vytvořit pracovni skupinu, která by úspěšně aplikovala marx-leninské zásady na obor hudebni kritiky, theorie a vědy, a která by tak účinně pomáhala vývoji naši hudby k socialistickému realismu. Je pochopitelné, že u některých to jsou rozpaky, jak na to. Nabizi se však otázka, zda někteři nezůstávají úmyslně stranou. " ${ }^{16}$ Za hlavní mluvčí ideologie socialistického realismu musíme sice označit především členy pražského ústředí, většinou funkcionáře představenstva Svazu československých skladatelů či přímo Ústředního výboru Komunistické strany: hudebního historika, kritika a politruka Zdeňka Nejedlého, hudebního teoretika a estetika Antonína Sychru, muzikologa, kritika a pedagoga Jaroslava Jiránka, šéfredaktora Hudebních rozhledů, publicistu Bohumila Karáska, skladatele, publicistu a svazového činovníka Miroslava Barvíka, muzikologa Ivana Vojtěcha a dále skladatele Josefa Stanislava, Václava Dobiáše, Jana Seidla, Jaroslava Tomáška ad. Pro naše sledování je však mimořádně zajímavé, jakým způsobem sestupovala ideologická frazeologie do nižších pater, jak byla využivána či zneuživána bez většinou zbytečné snahy o důslednější porozumění. Pro dokreslení situace tak upozorněme např́iklad na článek Věry Dolanské v Hudebních rozhledech 1951, věnovaný otázce rozvíjení lidové tvořivosti „I $v$ naší hudebni vědě a národopisu dodnes usilujeme o odstraněni nejhoršich následkủ kapitalistického soukromopodnikatelství. Odtrženost od praxe, dosavadni nepohotovost reagovat na aktuální události nového života, právě tak jako úzký prakticismus jsou stejně nebezpečné dnešní vědecké práci. Jsou pozůstatky apolitičnosti a netendenčnosti, kterou hlásala buržoasie, aby vědce odvedla od otevřených časových problémů. Typickým zatemňovacím manévrem bylo pěstování různých sobě odporujicich škol a směrů a žárlivé střežení vlastni pracovni methody i výsledků práce..." ${ }^{17}$ Je tudíž patrné, že vše mělo být jinak, jedinou možnou metodou byl zfušovaný marxismus, podmínkou byla práce $\mathrm{v}$ kolektivu a vystavování se stranické kritice a sebekritice a to za jediným účelem budování socialismu. Od počátku činnosti brněnské odbočky byl v nejužším vedení Jan Racek ${ }^{18}$, tudíž si dovolím na jeho príikladu ukázat, co se od hudebních vědců rámcově očekávalo. Rád bych upozornil na fakt, že neustále docházelo

16 Tvưrčí úspěchy moravských skladatelů. In. Hudební rozhledy, 1951, roč. 3, č. 7, s. 7.

17 DOLANSKÁ, Věra. Úkoly hudební vědy v rozvoji lidové tvořivosti. In. Hudební rozhledy, ročník 4, č. 6, s. 7.

Byl zvolen do výboru odbočky hned na prvním zasedání 20. listopadu 1950. Srov. 
k zaměňování vědeckého bádání s kritikou a především objektivita musela být nahrazována stranickou propagandou. ${ }^{19}$ Tak napríklad 21. února 1950 byl Racek společně s Jaroslavem Kvapilem, Janem Plichtou a Jiř́m Vysloužilem pověřen vypracováním sborníku masových písní a přípravou vystoupení v továrnách. 28. března pak přednesl referát, úvodní proslov k diskusi s názvem: $O$ tvưrči problematice v oblasti hudby. Úkoly a cíle nejmladši skladatelské generace, byl členem vydavatelské komise a pro 4. číslo 4. ročníku Hudebních rozhledů v roce 1951 prripravil článek Hudebni mluva ve světle marxistické jazykovědné theorie (Př́spěvek $k$ otázce tř́lního charakteru hudebni mluvy). ${ }^{20}$ Rackova pozice však byla poměrně složitá, neustále byl napadán za individualismus (samostatnost) a tudíž odtržení od kolektivu, bylo mu vytýkáno, že hudební věda se izoluje od aktuálních problémů a obzvláště z řad mladých kádrů Gustava Křivinky a Jaroslava Podešvy se mu dostávalo velmi nevybíravé ideologické kritiky. ${ }^{21}$ Negativní postoj $\mathrm{k}$ Rackovi měl hlavní předpoklad $\mathrm{v}$ diskusích nad jeho projevem na již několikrát zmiňované první brněnské plenárce v prosinci 1950: „Přiznačné je, že v tomto proslovu neřekl dr. Racek nic konkrétního ke skladbám, hraným na plenárce! Neexistuje véda pro védu a námitky prof. Josefa Stanislava, který se léta obirá theorii socialistického realismu, námitky prof. Václava Dobiáše a námitky generálního tajemnika Miroslava Barvika proti určitým thesím vyslovených dr. Rackem $v$ internich diskusích před zahájením plenárky (generační problém, nedialektický pohled na vývoj, jednostranný obhajoba Janáčka proti našim vulgomarxistům a levičákům, povšechné rady skladatelüm apod.) to neni náhodný zjev. Čekáme od prof. dr. Racka otevřené slovo - slovo poctivé sebekritiky a revise dosavadni cesty. Slovo stranického vědce, který dovede najít cestu na základě marx-leninské

PANTU゚ČEK, Viktor. Vznik brněnské odbočky Svazu československých skladatelů 19491951. Opus musicum, 2012, roč. 44, č. 2, s. 39.

19 Srov. CHRENNIKOV, Tichon. O stavu a úkolech hudební kritiky. In. Hudební rozhledy, 1951, roč. 3, č. 1, s. 4-9.; LĚBĚDJANSKIJ, Michal Sergejevič. Nerozřešené otázky hudební vědy. In. Hudebni rozhledy, 1951, roč. 3, č. 2, s. 25-26.; SYCHRA, Antonín. Nejnaléhavější úkoly hudební vědy a kritiky, Referát děkana hudební fakulty Akademie musických umění v Praze prof. dr. Antonína Sychry pronesený 10. II. na II. plenárním zasedání SČS. In. Hudební rozhledy, 1951, roč. 3, č. 10-12, s. 18-27.; KABALEVSKIJ, Dmitrij. Projevy zahraničních delegátů. K aktuálním otázkám hudební vědy a kritiky. In. Hudební rozhledy, 1951, roč. 3, č. 10-12, s. 28-29; OČADLÍK, Mirko. Diskuse o hudební vědě a kritice. Co nás čeká?. In. Hudební rozhledy, 1951, roč. 3, č. 10-12, s. 86-89.; Sovětská hudební věda náš vzor. In. Hudebni rozhledy, 1951, roč. 4, č. 4-5, s. 12.

20 Bibliografie Jana Racka byla sice poměrně pestrá, přesto jeho odbornost směřovala k poněkud jiným tématům. Srov. např. ŠTĚDROŇ, Miloš: Jan Racek: muzikologická osobnost mezi epochami (marginálie) In. MACEK, Petr; PEČMAN, Rudolf (ed.). Musicologica Brunensis Ad honorem Jan Racek, Bohumir Štědroň et Zdeněk Blažek 1905-2005, KLP Praha, 2005, s. 67-72.

21 Důležitou platformou pro argumentaci vǔči vědeckým pracovníkům byly materiály spojené s I. ideologickou konferencí vysokoškolských vědeckých pracovníků, která se uskutečnila na přelomu února a března 1952 v Brně. Srov. NEJEDLÝ, Zdeněk, ŠTOLL, Ladislav. Věda jde s lidem. Orbis, Praha, 1952. 


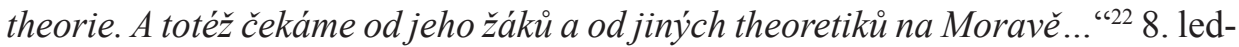
na 1951 zaslal Jan Racek vedení odbočky dopis, ve kterém se z důvodu velké pracovní vytíženosti vzdal členství ve výboru pobočky. Koncem roku 1951 se pak konalo v Brně celostátní setkání hudebních vědců, které však skončilo poměrně nezdarem, jelikož se jej nikdo z pražského ústředí nezúčastnil, každopádně v reakci na vznik celostátní sekce hudebních vědců pod Svazem československých skladatelů zde byl prodiskutován plán činnosti připravovaného samostatného brněnského kolektivu. Hudebně vědecký kolektiv byl tedy ustaven až na základě změny organizačního řádu $\mathrm{k} 1$. lednu 1952. První schůzka kolektivu se konala 18. března (tedy krátce po I. ideologické konferenci vysokoškolských vědeckých pracovníků, kde zazněly velmi nebezpečné projevy Zdeňka Nejedlého a především rektora Vysoké školy politických a hospodářských věd Ladislava Štolla, který mimo jiné nikdy nesložil maturitu ${ }^{23}$ na Filozofické fakultě Masarykovy univerzity, na pořadu bylo projednání plánu. „Plán je sice obsáhlý, ale nakonec se ukázalo, že se dá zmoci. Po projevu s. Vojtěcha následoval referát prof. Černušáka. Přitomno bylo 20 mladšich i staršich pracovniku. Schize trvala čtyři a půl hodiny. Diskuse byla bohatá a plodná. Z diskuse pak vyplynulo, že se má pokračovat v práci na Pazdirkově hudebním slovníku. Za redakce prof. Černušáka se bude pracovat na osobnim Českém hudebnim slovniku. Je potřeba finanční zajištěni a jednu pracovni sílu [...]. Koncem května výstava hudebních nástrojů společně s museem. Připravné práce na vybudováni hudebně historického ústavu a zř́zení Janáčkova musea. Pracovní závazky učinili na schůzi soudruzi: Dr. Burjanek, prof. Černušák, Dr. Hlaváček, Dr. Lýsek, Přemysl Novák, Dr. Racek, Dr. Straková, Dr. Štědron̆, Dr. Vetterl, Vojtěch a Pohanka. Kolektiv se bude scházet tehdy, kdy toho bude zapotřebí. V diskusi budou přednášeny konkrétni referáty." ${ }^{24}$ Hudebně vědecký kolektiv při ústavu hudební vědy filosofické fakulty Masarykovy university v Brně měl k roku 195222 členů ${ }^{25}$, byl rozdělen do tř́ pracovních skupin: Hudebně historická, Esteticko kritická a Hudebně lidopisná. Byly stanoveny naléhavé úkoly pro jednotlivé skupiny.

\section{„Hudebně historická skupina:}

Nové prehodnocení a osvětleni díla Leoše Janáčka

- Př́prava do tisku všech Janáčkových děl literárnich a hudebnè theoretických.

22

Tvůrčí úspěchy moravských skladatelů. In. Hudební rozhledy, 1951, roč. 3, č. 7, s. 8

OLŠÁKOVÁ, Doubravka. Věda jde k lidu! : československá společnost pro šírení politických a védeckých znalostí a popularizace věd v Československu ve 20. stolení. Praha: Academia, 2014, s. 24.

Zápis výborové schůze brněnské odbočky SČS, konané dne 24. 3. 1952 v sekretariátě, uloženo v Oddělení dějin hudby MZM.

Josef Burjanek, Gracián Černušák, Jiří Hlaváček, Zdenka Jelínková, Ludvík Kundera, František Lýsek, Přemysl Novák, Ludvík Podéšt', Jan Racek, Theodora Straková, Věra Střelcová, Jiř́i Svoboda, Bohumír Štědroň, Karel Vetterl, Ivan Vojtěch, Jiř̌́ Vysloužil, Petr Adler, František Hrabal, Miloš Masařík, Jaroslav Nečas, Rudolf Pečman, Ivo Stolařík. Srov. Hudebně vědecký kolektiv při ústavu hudební vědy filosofické fakulty Masarykovy univerzity v Brně, 1952 - uloženo v oddělení dějin hudby MZM 
V̌se se již opisuje. Práce této edice je rozpočtena přibližně na 3 roky. Bude to celkem 5 svazki.

- Janáckovy theroretické práce o lidové písni

- Studie o nápěvcich mluvy

- Janáčkovy literárni stati a feuilletony

- Práce a studie hudebně výchovné

- Studie hudebně estetické a theoretické. Fragmenta.

Vedoucí Edice janáčkovských pramenü: Dr. J. Racek-T. Straková

Dëjiny hudby a jejich periodisace.

Vedoucí: Černušák, Racek, Štědroň a Vojtěch

Slovanské prvky v české hudbě a mezislovanské styky.

Vedouci: Černušák, Racek, Štědroň a Vojtěch

Česká hymnologie. Edice Komenského kancionálu.

Redakce: Racek, Štědron̆

Praxe: Vybudovat Janáčkovo museum v Brně a to na podkladě socialistické museografické methody. Spojit spolu se Stát. ústavem pro lid. piseň a hudebně historickým oddělením Moravského musea.... Organisace výstav, historické koncerty soudobé hudby na nádvoři musea podle vzoru loňských gramo večerü. Pořádat velké výstavy hudebního materiálu v rámci činnosti Moravského musea. Pravá velká plánovaná výstava Hudební nástroje ve společenském vývoji lidstva. Zde bude provedena aplikace periodisace světových dějin, jež bude definitivně prodiskutována na prvém zasedáni hud. védeckého kolektivu. Budou se pořizovat excerpta pro Pazdirkưv hudebni slovnik a tak připravovat materiál k dalši práci na tomto slovníku. Později až bude k tomu materiál, který získáme činností na schůzích hud. věd. skupiny, budeme vydávat dalši III. svazek Musikologie, kterou postupně prebudujeme na Slovanskou musikologii s přispěvky v pưvodnich slovanských jazycích.

Vedouci praxe: Burjanek, Novák, Straková

\section{Esteticko kritická:}

Problém hudebniho zobrazováni a hudebniho myšlení. Programovost hudby $v$ hudbě orchestrální, komorni a hudebně dramatické.

Vedouci: Burjanek, Racek, Novák, Vojtěch

Janáček a opera. Kladný přinos Janáčkův do slovanského operního typu. Srovnávací studie Janáčkových libret na ruská themata (např. Káta Kabanová - Ostrovského Groza, Mrtvý dům - Dostojevského román)

Problémy současné moravské hudebni tvorby, kritika, výhledy.

Vedouci: Burjanek, Hlaváček, Novák, Kundera, Střelcová, Svoboda, Vojtěch.

Praxe: Operni kolektiv, diskuse ve Svazu, rozhlas, aktuální problémy, tisk, propagace.

Vedoucí: Burjanek, Novák, Straková, Lýsek, Vojtěch

\section{Hudebně lidopisná:}

Vybudováni melodického alfabetu na základě historicko srovnávaci methody a dialektického vývoje lidové pisně v lidské společnosti. Kritika starších idealis- 
ticko buržoasnich theorií. Sovětská hudebně lidopisná literatura a nové pracovní methody. Edice Guberniálni sbirky. Spolupráce s ústavem lidové písnè.

Vedoucí: Zd. Jelinková, Fr. Lýsek, Jan Racek, Karel Vetterl.

Praxe: Součinnost se Státním ústavem pro lid. písen̆, SČS v Brně (spojitost lidové písně a hudby s hudbou umělou), organisace sběrů, přednášková činnost aj.

Vedoucí: Zd. Jelinková, Fr. Lýsek, Karel Vetterl

Základ veškeré práce bude práce individuální, jež bude čas od času přednesena ve formě referátů, jež budou prodiskutovány v kolektivu. Ukázky z prací. Naše plány a práce bude vždy koordinována s hudebněvedeckou skupinou v Praze, Olomouci a Bratislavě, aby nedošlo ke zbytečným pracovním kolisím a neekonomii práce.

Přípravy k hudebně vědeckým konferencím (2 konference Zd. Nejedlý a jeho dílo, 3 konference o dějinách hudby."“26

Většina stanovených úkolů, myšleno statisticky, byla splněna pouze z části, po stránce obsahové, tedy dobově ideologické, pak došlo k naplnění pouze minima předsevzetí. Bylo to dáno, jak změnou politické situace po krachu první pětiletky a smrti Stalina a Gottwalda v roce 1953, tak mimořádnou administrativní a „budovatelskou“ vytížeností hlavních představitelů hudebně vědeckého kolektivu. Tak například už k 1. květnu 1949 byl Ludvík Kundera prvním rektorem JAMU, redaktorem kritické rubriky dožívajících Lidových novin, předsedou Hudební artistické ústředny, předsedou místní odbočky Syndikátu českých skladatelů a předsedou komise KSČ. Až do roku 1954, kdy byl schválen nový organizační řád, a kolektivy byly nahrazeny samostatnými sekcemi, se jak jednotliví členové či kandidáti, tak celý kolektiv potýkali s řadou problémů. Opět si dovolím situaci osvětlit na př́kladu Jana Racka. Z důvodu reorganizace Svazu probíhaly pohovory s jednotlivými členy, tím byla pověřena tvưrčí komise, jelikož však nápor nezvládala, přistoupilo se 21 . ledna 1952 k vytvoření tř́ zvláštních komisí - členem třetí komise byl vedle Josefa Burjanka a Přemysla Nováka jmenován Jan Racek, ačkoliv se sám musel podrobit pohovoru - zvláštní komise začala fungovat prvního února a scházela se jednou týdně. ${ }^{27}$ Hudebně vědecký kolektiv si budoval zdánlivou samostatnost a to se samozřejmě nemohlo podporovat, 5 . května 1952 tak bylo vedení kolektivu vytknuto, že se dopouštějí organizační chyby, když uvádějí pozvánky pouze hlavičkou „hudebně vědecký kolektiv při MU v Brně“ - bez odkazu na SČSS. ${ }^{28}$ Otázka osamostatňování hudební vědy byla poté řešena na schůzi 20. května, byl konstatován „nedostatek ve vedeni Svazu, pokud se týče hudebni vědy. Přičleněni hudební vědy $k$ Akademii se jeví jako únik ze Svazu, ne progresivni přičlenění. V brněnské odbočce u některých soudruhì

26 Hudebně vědecký kolektiv při ústavu hudební vědy filosofické fakulty Masarykovy univerzity v Brně, 1952 - uloženo v oddělení dějin hudby MZM.

27 Zápis o schůzi výboru brněnské odbočky SČS, konané dne 21. ledna 1952 v sekretariátě Ul. 9. května č. 2/III. posch. - uloženo v oddělení dějin hudby MZM.

28 Zápis z výborové schůze brněnské odbočky SČS, konané dne 5. května 1952 v 19 hodin $\mathrm{v}$ sekretariátě - uloženo v oddělení dějin hudby MZM. 
je nebezpeči isolace, konkrétně hudební věda, s. Racek. Bude pozván k pohovoru do našeho výboru. “29 Situace se dále vyostřovala, když na stranické desítce Jaroslav Podešva vyslovil mínění, že je prof. Racek individualista a ,že by se mohl dostat do nebezpečné posice. “" Rackova obhajoba na výborové schůzi dne 16. června 1952 pak byla následující: cituji ze zápisu „Nebyl a nechce být individualistou. Rozdává velmi nezištně své vědomosti. Nemůže provádět konsultace s posluchači tak, jak by chtěl, poněvadž je př́liš zaneprázdněn. Bylo by smutné, kdyby se společnost zbavila individuality. Cituje, co ř́ḱk Marx o individualitách. $V$ historii je potřeba individuality. Klade na to velký di̊raz. Č́m jich bude vic, tím bude společnost pevnější. Je potřeba individualit mravných a poctivých. Jeho ctižádostí je, aby se stal touto individualitou. Zná dobře hodnotu práce a uzná vždy práci ostatnich, posuzuje ji ale prísně ze svého stanoviska. Dělá chyby, ale uči se. Tato práce je nékdy mařena, zneklidňována a do jisté miry mu to vadí. $Z$ překroucených informaci se dělaji někdy nesprávné závěry. Kritika neopřená o znalosti, není kritikou. Neoprávněná kritika mladých.“ A pokračuje: „Potřebujeme penize na hudebnè védecký slovník, soudruzi slíbili, že je to samožrejmé, penize budou a nyní se v Praze velmi podivili, že chceme penize. Je třeba, aby se tyto věci vyjasnily, protože jsme za tuto práci zodpovédni. Musíme lidem věrit, dát jim možnost, aby mohli v klidu rozvijet svoji práci. Vztah člověka k člověku se lepší. Kritika nesmí být terorizováním apod. Individualismus vidí např. v tom, že napíše dopis Karáskovi, dá si s ním práci, on neodpoví. Od s. Kauckého rovněž nedostal odpověd'. Nesvědči to o posici kolektivistické, ale krajně individualistické. Za všech okolností bude bojovat proti vědeckému tmářství, proti lži a terorisování. Za zdravého člověka, vědce, umělce, prostého, upřimného člověka socialistického, ne s př́zemními touhami pozemními. Bude vystupovat vždy otevřeně. " ${ }^{31}$ Zápisy z brněnských výborů byly zasílány na ústředí do Prahy, což ještě vyostřovalo situaci. K vyhrocení pak došlo na schůzi 30. června. Racek nejprve konstatoval, že plán byl splněn na $100 \%$, předseda odbočky Kundera ocenil, že kolektiv začíná pracovat. Následovalo postesknutí na nedostatečnou komunikaci s Prahou. Poté však Gustav Křivinka prohlásil, že „práce hudebnich vědců nesmí být odlučována od odbočky. Musí zde být těsná součinnost. Výbor má právo vědět co se děje v kolektivech." Do diskuse vstoupil Ivan Vojtěch, který se postavil na stranu kolektivu „hudebně vědecký kolektiv odpovidá organisačně hudebně vědecké sekci, ne odbočce. Sekce by pak byla zbytečný orgán. Odbočky mohou kritizovat, ale nemaji právo ř́dit práci hudebně vědeckého kolektivu. "V poměrně ostré polemice, kdy na jedné straně se profiloval Křivinka, Podešva, Podéšt' a Kundera a na druhé Racek s Vojtěchem, pak Vojtěch př́mo napadl vedení odbočky, kdy prohlásil, že kádrové věci má řešit hudebně vědecká sekce a dále:

29 Zápis z výborové schůze brněnské odbočky SČS, konané dne 20. května 1952 v 19 hodin v sekretariátě - uloženo v oddělení dějin hudby MZM.

30 Zápis z výborové schůze brněnské odbočky SČS, konané dne 16. června 1952 v 19 hodin v zasedací síni SČS - uloženo v oddělení dějin hudby MZM

31 tamtéž 
„záleži velmi na tom, jak se kritisuje. Otázka vstupu hudebni vědy do Akademie - na základě čeho se odbočka o tom bavila, nespadá to do její kompetence.“32 Výsledkem byl dopis Ivana Vojtěcha, ve kterém si stěžuje, že jej Křivinka s Podešvou obvinili z pletich. ${ }^{33}$ Situace se nakonec vyřešila smírně, Křivinka napsal dopis Rackovi, kde mu vysvětlil situaci a podal sebekritiku, poté zajistil u Barvíka, „aby dal opravu do príštího čisla Informačních zpráv pro funkcionáře, ve kterém byla zpráva o situaci v brněnské hudebni vědě. ${ }^{\text {" } 34}$ Činnost kolektivu mohla pokračovat v zaběhnutých, i když značně pokřivených, kolejích.

Viktor Pantůček (pantucek@phil.muni.cz), Ústav hudební vědy, Filozofická fakulta, Masarykova univerzita, Brno.

\section{ABSTRACT \\ MUSICOLOGICAL COLLECTIVE HAS ALREADY ACHIEVED PRETTY GOOD RESULTS. NON-UNIVERSITY MUSICOLOGY IN THE FIRST HALF OF 1950s IN BRNO.}

The presented case study, which from the microhistorical point of view is defined geographically rather than purely anthropologically, is built on the blending as well as the contradiction of the social requirement for a clear, though indefinable, artistic doctrine and its fulfilment or non-fulfilment, both in the issues regarding the distribution of the "canon" among musicians as well as within the whole of society (i.e. as an analysis of the system and the organization of musical life) and on the aesthetic level (i.e. the change in language itself). Inspired by Foucault, I am looking for "collective discourses", and I describe power "strategies" according to Bourdieu, but I characterize the chosen period and mainly the location rather using the "tactics of the subjects", whose freedom was significantly curtailed, and the "practices" or even "do-it-yourself activities" of the newly "constructed" community of those in power. I would like to show such tactical acting and do-it-yourself activities in terms of the activities of the musicology team of the Union of Czechoslovak Composers, and more generally, the issue of the status of musical science in society.

\section{Key words}

music, Czech Music, Brno, 2nd half of the 20th century, Musicology, the Union of Czechoslovak Composers, socialist realism

\section{Bibliography}

APPLEBAUMOVÁ, Anne. Železná opona Podrobeni východni Evropy 1944-1956. Praha - Plzeň: Beta-Dobrovský Ševčí, 2014.

32 Zápis z výborové schůze brněnské odbočky SČS, konané dne 30. června 1952 v 19 hodin v sekretariátě. - uloženo v oddělení dějin hudby MZM

33 Zápis z výborové schůze brněnské odbočky SČS, konané dne 8. září 1952 v sekretariátě v 19 hodin. - uloženo v oddělení dějin hudby MZM

34 Zápis z výborové schůze brněnské odbočky SČS, konané dne 31. řijina 1952 v 19 hodin v sekretariátě odbočky. - uloženo v oddělení dějin hudby MZM 
BARVÍK, Miroslav. Návrh osnov dějin hudby na konservatoři. In. Hudebni rozhledy, 1951, roč. 4, č. 3, s. 12-13.

BERGER, Roman. Dráma hudby Prologomena k politickej muzikológii. Bratislava: Hudobné centrum, 2000.

DOLANSKÁ, Věra. Úkoly hudební vědy v rozvoji lidové tvořivosti. In. Hudebni rozhledy, ročník 4, č. 6, s. 7-11.

HAVLÍK, Jaromír. Jaroslav Doubrava. Skladatel v sevření dvou totalit. Praha: NAMU, 2002.

Hudebně vědecký kolektiv při ústavu hudební vědy filosofické fakulty Masarykovy univerzity v Brně, 1952 - uloženo v oddělení dějin hudby MZM.

CHMELAŘOVÁ, Vlasta. Syndikát českých skladatelů, In. Kolektiv autorů. Slovník české hudební kultury. Praha: Editio Supraphon, 1997, s. 901.

CHRENNIKOV, Tichon. O stavu a úkolech hudební kritiky. In. Hudební rozhledy, 1951, roč. 3, č. 1, s. 4-9.

KABALEVSKIJ, Dmitrij. Projevy zahraničních delegátů. K aktuálním otázkám hudební vědy a kritiky. In. Hudebni rozhledy, 1951, roč. 3, č. 10-12, s. 28-29.

KAPLAN, Karel. Protistátni bezpečnost 1945-1948 Historie vzniku a působeni STB jako mocenského nástroje KSČ. Praha: Plus, 2015, s. 490.

KNAPÍK, Jiří. V zajetí moci. Kulturní politika, jeji systém a aktéŕi 1948-1956. Praha: Libri, 2006.

LĚBĚDJANSKIJ, Michal Sergejevič. Nerozřešené otázky hudební vědy. In. Hudebni rozhledy, 1951 , roč. 3, č. 2, s. 25-26.

LUKEŠ, Igor. Československo nad propasti Selhání amerických diplomatů a tajných služeb v Praze 1945-1948. Praha: Prostor, 2014.

MUKAŘOVSKÝ, Jan. Stranickost ve vědě a umění. Praha: Orbis, 1949.

NEJEDLÝ, Zdeněk; ŠTOLL, Ladislav. Věda jde s lidem. Praha: Orbis, 1952.

OČADLÍK, Mirko. Diskuse o hudební vědě a kritice. Co nás čeká?. In. Hudební rozhledy, 1951, roč. 3, č. 10-12, s. 86-89.

OLŠÁKOVÁ, Doubravka. Věda jde k lidu! : československá společnost pro šírení politických a vědeckých znalostí a popularizace věd v Československu ve 20. stolení. Praha: Academia, 2014.

Organizační řád Svazu československých skladatelů + poznámky, 1950 - uloženo v Oddělení dějin hudby MZM.

PANTU゚ČEK, Viktor. Musica politica Budování nového řádu. Opus musicum Hudební revue, Brno, 2007, roč. 39/2007, č. 1, s. 36-37.

PANTƯČEK, Viktor. Vznik brněnské odbočky Svazu československých skladatelů 1949-1951. Opus musicum, 2012, roč. 44, č. 2, s. 37-48.

Sovětská hudební věda - náš vzor. In. Hudebni rozhledy, 1951, roč. 4, č. 4-5, s. 12.

SYCHRA, Antonín. Nejnaléhavější úkoly hudební vědy a kritiky, Referát děkana hudební fakulty Akademie musických umění v Praze prof. dr. Annonína Sychry pronesený 10. II. na II. plenárním zasedání SČS. In. Hudební rozhledy, 1951, roč. 3, č. 10-12, s. 18-27.

ŠTĚDROŇ, Miloš: Jan Racek: muzikologická osobnost mezi epochami (marginálie) In. MACEK, Petr; PEČMAN, Rudolf (ed.). Musicologica Brunensis Ad honorem Jan Racek, Bohumir Štědron̆ et Zdeněk Blažek 1905 - 2005, KLP Praha, 2005, s. 67-72.

Tvůrčí úspěchy moravských skladatelů. In. Hudební rozhledy, 1951, roč. 3, č. 7, s. 4-9.

Zákon o Československé akademii věd č. 52 / 1952 z 29. října 1952.

Zápis o schůzi výboru brněnské odbočky SČS, konané dne 21. ledna 1952 v sekretariátě Ul. 9. května č. 2/III. posch. - uloženo v Oddělení dějin hudby MZM.

Zápis výborové schůze brněnské odbočky SČS, konané dne 24. 3. 1952 v sekretariátě, uloženo v oddělení dějin hudby MZM

Zápis z výborové schůze brněnské odbočky SČS, konané dne 16. června 1952 v 19 hodin v zasedací síni SČS - uloženo v oddělení dějin hudby MZM

Zápis z výborové schůze brněnské odbočky SČS, konané dne 20. května 1952 v 19 hodin v sekretariátě - uloženo v oddělení dějin hudby MZM. 
Zápis z výborové schůze brněnské odbočky SČS, konané dne 30. června 1952 v 19 hodin v sekretariátě. - uloženo v oddělení dějin hudby MZM

Zápis z výborové schůze brněnské odbočky SČS, konané dne 31. října 1952 v 19 hodin v sekretariátě odbočky. - uloženo v oddělení dějin hudby MZM

Zápis z výborové schůze brněnské odbočky SČS, konané dne 5. května 1952 v 19 hodin v sekretariátě - uloženo v oddělení dějin hudby MZM.

Zápis z výborové schůze brněnské odbočky SČS, konané dne 8. září 1952 v sekretariátě v 19 hodin. - uloženo v oddělení dějin hudby MZM

Záznam o činnosti Klubu SČS v Brně dne 28. června 1950. Přehrávka skladeb Chlubny a Petrželky; DkCHK00000357.

ŽDANOV, Andrej Alexandrovič.: O problémech sovětské hudby, 1948 In. Konfrontace 2 Měsičník pro soudobou hudbu. Svaz českých skladatelů, Praha 1969, s. 54. 
